\title{
The institutional and socio-technical determinants of renewable energy production in the EU: implications for policy
}

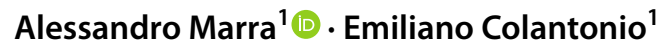

Received: 9 January 2022 / Revised: 11 February 2022 / Accepted: 14 February 2022 /

Published online: 1 March 2022

(c) The Author(s) 2022, corrected publication 2022

\begin{abstract}
Despite the consensus that the transition to renewable energy is a process that encompasses institutional, regulatory, technical, political, social, and cultural aspects, such issues have rarely been addressed in a comprehensive way. This study explores the determinants of renewable energy production (REP), focusing on institutional and socio-technical aspects. We employ a panel vector autoregressive (PVAR) model to test dynamic relationships for the period 1990-2015 among several variables, as have emerged in the literature: REP, policy stringency, public awareness, lobbying, education, controlling for income and energy imports. Focusing indiscriminately on 18 European Union (EU) member states, the results show that environmental policy stringency does not influence REP, while income and education impact negatively. This evidence is counter-intuitive, and would be surprising if we did not consider the strong heterogeneity between countries. EU member states are engaging in energy transition at different speeds, depending on their individual starting point: this differs from country to country in terms of installed capacity and energy security. Moving from the recent European Green Deal, we divide the sample into two panels based on energy imports to account for different starting points: countries less active on the production side (that depends particularly on energy imports), and countries more active on the production side. Results for the first panel show that an increase in policy stringency would lead to a decrease in lobbying and an increase in REP. Policy efforts must be clearly established and consistently preserved to support REP, at least if there are increasing returns to exploit. Results for the second panel show that lobbying negatively affects the transition to REP, while an increase in public awareness will promote an increase in REP. Therefore, priority should be given to the 'social' aspect, and policymakers should increase efforts to reduce the proportion of energy generated from oil, natural gas, coal, and nuclear fuel.
\end{abstract}

Extended author information available on the last page of the article 
Keywords Renewable energy production $\cdot$ Environmental policy $\cdot$ Public awareness $\cdot$ Lobbying $\cdot$ Education $\cdot$ Income $\cdot$ Energy imports

JEL Classification Q40 · Q28

\section{Introduction}

Renewable energy sources are emerging as an important component with regard to meeting global energy demand. According to the International Energy Agency (IEA, 2019), the capacity for renewable power will increase by $50 \%$ in the coming years. Solar photovoltaic energy accounts for $60 \%$ of the expected growth, onshore wind accounts for $20 \%$, and offshore wind for only $4 \%$. The last of these is expected to triple in capacity by 2024 , thanks to competitive auctions in the European Union (EU) and market expansion in China and the United States (US). In addition, bioenergy capacity is expected to increase, especially in China, India, and the EU. The increase in hydropower will decelerate, although it will still account for $10 \%$ of the growth in renewable energy (IEA, 2019). In 2020, the deployment of renewable energy for generating electricity has increased by $7 \%$ : the Covid-19 crisis has not halted its growth (IEA, 2020).

In the EU, primary renewable energy production (REP) increased by $49 \%$ between 2008 and 2018. The most important source was wood and other biofuels, which accounted for more than $40 \%$. Wind power accounted for $14 \%$ of the total, confirmed as the second main source, followed by hydro power with $11 \%$ of the total. Despite low levels of production, the output of biogas, liquid biofuels, and solar energy increased fast, accounting for a 7\%,7\%, and 6\%, respectively of the EU's REP (EC, 2021). Although the installed capacity for REP is increasing, considerable differences remain within the EU. In 2018, renewable energy shares varied considerably across EU member states, ranging from 15 to $100 \%$. Such differences are expected to continue because of the persistence of country-specific conditions, different starting points, and existing policies (IRENA, 2018).

A growing literature has emerged to identify the factors that prompt renewable energy at the national level (Gan \& Smith, 2011; Marques \& Fuinhas, 2011). However, the understanding of its determinants remain incomplete, due to the use of different methodologies and frameworks, and to the lack of a comprehensive focus on institutional and socio-technical issues (Bourcet, 2020; Can Şener et al., 2018).

First, there is limited understanding regarding the determinants of REP, even though some agreement has emerged on a couple of mechanisms: regulatory and environmental policies have a positive effect, while lobbying in favour of traditional energy sources produces a negative effect. Secondly, despite the consensus that the transition to renewable energy is a process that encompasses institutional, regulatory, technical, political, social, and cultural aspects, such issues have been rarely addressed in a comprehensive way in the literature (Andrews-Speed, 2016; Sovacool, 2009). 
Some energy companies still reject renewable resources because they prefer big and conventional power plants. Many consumers do not fully appreciate the benefits deriving from more renewable systems in terms of the reduction of carbon dioxide emissions. Sometimes public authorities are not able to set up the 'right' system or provide the 'right' incentives to encourage more renewable production. In such circumstances, institutional and socio-technical issues act as impediments and barriers to renewable deployment. Nonetheless, such aspects need to be adequately understood to realize how renewable energy is going to expand in the future: while technological advances are important, resistance from firms, consumers and public authorities can impede or slow the transition considerably (Smith et al., 2005). Improved understanding of such institutional and socio-technical factors will allow scholars and policymakers to provide forecasts for renewable energy that are better grounded in the socio-political context (Andrews-Speed, 2016).

Today, compared to a few years ago, we appreciate to a greater extent the increased public awareness of the dangers of climate change, the desirability of using renewable energy, the growing adoption of environmental policy measures and incentive schemes to boost clean energy deployment, and the common acceptance of the green paradigm by both large multinationals and small and mediumsized enterprises.

All this calls for a need to revisit the determinants of REP and a need to focus on the socio-technical aspects. The purpose of the study is to investigate the determinants of REP in different EU member states while controlling for income and energy imports, focusing on several institutional and socio-technical aspects in the form of regulatory constraints and policy stringency, private interests and lobbying, environmental pollution and public awareness, technical understanding and the level of education. We employ a panel vector autoregressive (PVAR) model in first differences to test the complex dynamic relationships among the above variables for the longest time span possible-from 1990 to 2015 - for 18 EU member states.

Although there are some differences, all EU member states are expected to raise the level of production from renewable sources by employing several levers. Nonetheless, the results with regard to the entire sample of countries show that environmental policy stringency does not influence REP, while income and education impact negatively. This evidence is counter-intuitive and would be surprising if we did not consider the strong heterogeneity between countries. EU member states are engaging in a transition to REP at different speeds, based on their starting point: this differs from country to country in terms of installed capacity and energy security. More specifically, countries with relatively higher energy imports and lower installed capacity are expected to act more quickly, since they face lower obstacles to initiating a more vigorous transition to renewable energy (Kahia et al., 2017).

This same perspective has been adopted by the European Commission in the recent European Green Deal (EC, 2019). Accordingly, as suggested in the literature (Marques \& Fuinhas, 2012), we divide the sample into two panels, using the share of energy imports to account for the different starting points. Energy imports, combining installed capacity and energy security issues, properly condenses differing policy, strategic and industrial choices, and allows us to distinguish between 
countries that are less active in terms of production (depending on energy imports from third countries; panel A, high energy importers) and countries that are more active (panel B, low energy importers).

The remainder of the paper is organized as follows. Section 2 reviews the literature on the determinants of REP. Section 3 presents the empirical analysis, including the model specifications and the methodology used (Sect. 3.1), the testing framework (Sect. 3.2), and the results (Sects. 3.3 and 3.4). Conclusions and policy implications based on the findings are presented in Sect. 4.

\section{Literature}

The transition to renewable energy involves deep changes in society at different levels. Most of these changes can be framed within institutional theory, according to which institutions set the pace and the direction of economic and political development (Blyth, 2002; North, 1990, 2005). In the following review we intend to emphasise some key points in the literature on renewable energy in terms of institutional theory. Institutions, such as policy and regulation, exert a direct and noteworthy effect on renewable deployment. Secondly, analyses of policy and regulations need to consider path dependence as an indispensable element of transition processes. Lastly, institutions cannot be viewed as being isolated from the underlying sociotechnical substratum that generates them: governments are often necessary elements but are not sufficient in terms of these kinds of transitions.

In this section, we do not intend to provide a comprehensive overview of how institutional theory can help rationalise the energy transition, because such an attempt would go beyond the scope of the paper. In effect, institutions have been variously conceptualised, and there exist several strands of theory which need to be investigated (Andrews-Speed, 2016). We refer to further and more detailed literature on this theme (Nilsson et al., 2011; Smith et al., 2005).

Since the transition to renewable sources is a socio-technical process, we need to start somewhere to differentiate between institutional, regulatory, technical, political, social, and cultural aspects, even if any attempt to divide the technical from the political, or even the social from the technical is complicated, and misses the point that such aspects are fundamentally integrated. We focus on the main factors that, according to the literature, play a role in guiding the transition: regulatory constraints and policy stringency, environmental pollution and public awareness, private interests and lobbying, technical understanding and level of education, and controlling for income and energy imports.

The choice of the main determinants accounted for, and the proxies used in the empirical analysis, are coherent with the extant literature.

There is little doubt about the impact of regulatory constraints and policy stringency on the environment, even though there is no clear consensus on how to measure such aspects. Bird et al. (2005) contended that it is difficult to discern one single determinant of wind power development. Some of the determinants observed in 12 US Federal States include policy aspects such as renewable portfolio standards (RPS, a regulation that requires an increase in REP), federal and state financial 
incentives, and market drivers. More specifically, RPS appear to be the most successful. Menz and Vachon (2006) examined the policies adopted at state level to promote renewable energy. They found a substantial disparity among states in terms of the renewable power policies they adopt. Shrimali and Kniefel (2011) used data from over 50 US states for the time interval 1991-2007 and a model with statespecific trends to investigate the consequences of state policies on the diffusion of various renewable sources. RPS, with specific requirements in terms of capacity and sales, was found to generate significant effects on renewable energy deployment. Polzin et al. (2015) examined the consequences of public policy measures on renewable energy investment in capacity. The authors investigated the impact of different policies in OECD countries to identify an effective mix that could boost renewable energy. The findings suggest the need for policies that take account of market conditions and technological development. To increase investment, recommended policies include economic and fiscal incentives, specifically for new and emerging technologies. All the results reinforce the expected positive relationship between regulation and REP.

Composite indicators such as the Environmental Policy Stringency (EPS) index, have been largely used to explore the advantage of incorporating market-based and non-market-based regulations (Georgatzi et al., 2020; Ouyang et al., 2019). Although we could have relied on individual indicators such as feed-in tariffs, trading schemes, and taxes within the composite index, we opted for a more inclusive measure: the EPS index combines 14 different indicators into one single, comparable, country-specific proxy of policy stringency. Moreover, we checked for positive and significant correlations between market-based and non-market-based dimensions (0.53), and between each dimension and the composite index, and obtained 0.83 and 0.93, respectively (Hille \& Möbius, 2019).

As expected, income (taken as GDP per capita) is the economic variable most frequently used to explain renewable energy deployment. There is much debate as to whether or not, at least in advanced countries, higher income can be positively associated with higher energy production, both from renewable and non-renewable sources. The GDP effect has been tested recurrently in the literature (Alper \& Oguz, 2016; Menegaki, 2011; Narayan \& Smyth, 2008; Sadorsky, 2009a, 2009b). A greater income level is expected to be associated with greater renewable energy for two reasons: first, greater GDP implies more resources being available to implement and promote renewable energy; second, a greater income level implies greater potential to support higher policy costs (Chang et al., 2009). Conversely, Marques and Fuinhas (2011) found that income and the price of fossil-based fuels were not major factors in the deployment of renewable energy sources. Marques and Fuinhas (2012) analysed the relationships between energy sources and economic growth for 24 EU countries between 1990 and 2007, and suggested that the consequence of renewable deployment replaces the impact of generating income by using natural resources sourced locally. The major costs associated with supporting renewable sources tend to place an excessive burden on the economy, due to rising electricity tariffs.

Policy and economic variables have been used within more comprehensive frameworks to understand their role and scope. Carley (2009) appraised the 
implementation of RPS policy achieved by state energy programs working on a larger spectrum of variables: the author found that institutions, natural resources, deregulation, GDP per capita, electricity use per capita, electricity prices, and the presence of regional RPS were all related to renewable energy. Gan and Smith (2011) identified key factors that might drive different shares of renewable energy in terms of the energy supply among OECD countries. They found that, in addition to country-specific factors, GDP, along with renewable energy deployment policies, has a positive effect on the per capita supply of renewable energy. R\&D expenditure, energy prices, carbon-dioxide emissions, and other energy policies had no significant effect on renewable energy. Nonetheless, this does not necessarily mean they are not potential drivers; instead, it implies they were not of a magnitude sufficient to appreciably affect energy supply between 1994 and 2003.

Following Carley (2009) and Sadorsky (2009a), most of the literature introduced an environmental indicator in the form of carbon-dioxide emissions as a proxy for environmental concerns and degradation (Bourcet, 2020). Carbon dioxide emissions are positively associated with REP (Menegaki, 2011; Sadorsky, 2009a; Salim \& Rafiq, 2012; van Ruijven \& van Vuuren, 2009). This may be explained by the fact that a high level of carbon dioxide emissions causes an increase in the demand for environmental protection. Nonetheless, Marques and Fuinhas (2011) showed that public awareness of environmental issues and carbon dioxide targets are not sufficient in themselves to encourage a shift to renewable energy. Citizens should carry the initial economic costs by supporting policy costs such as paying higher prices and taxes.

Likewise, the role that the dependency on fossil fuels and the power of lobbies might play in balancing out environmental policies has been widely debated (Marques \& Fuinhas, 2011; Marques et al., 2010). Marques et al. (2010) showed that lobbying for fossil sources reduces renewable use. Marques and Fuinhas (2011) explored the commitment to renewable energy in 24 EU member states, and showed that non-renewable energy sources restrain the stimulus towards renewable energy. The development and growth of renewable energy can be prevented by interest groups, including trade associations associated with the fossil and nuclear energy sectors, which could increase the percentage of fossil- and nuclear-based energy. The ease with which fossil resources can be stored, and the already-installed capacity, might justify why the deployment of renewable energy is hampered. Since the effect of lobbying is suggested to be a major determinant (Huang et al., 2007; Sovacool, 2009), we opted for including such a dimension in the analysis.

It is commonly accepted that energy imports are inversely correlated with the installed capacity of traditional energy sources and, consequently, have negative repercussions on the industrial choices and strategies that can be pursued in terms of renewable energy production (Kahia et al., 2017). The share of energy imports is, at the same time, a starting point and an industrial policy lever with regard to ensuring energy self-sufficiency and security (Narbel, 2013; Valdés Lucas et al., 2016). Even though there is consensus in recognizing a negative association between energy imports and the deployment of renewable energy (Marques et al., 2010), this relationship is not always empirically confirmed (Marques \& Fuinhas, 2012). 
To better discern the underlying relationships between the above discussed sociotechnical variables, we added a further interpretative element by introducing the variable education in the sense that this can generate reinforcing mechanisms to the advantage of the environment and renewable sources (Xie et al., 2017).

Vachon and Menz (2006) examined the impact of social, political, and economic interests on the propensity to implement renewable energy policies. The results suggest that social interests, measured by income, education, and involvement in environmental lobbying, were associated with the adoption of green policies. Furthermore, the authors explained that an understanding of the advantages of environmental policies is positively correlated to levels of education for several reasons, including a more cogent appraisal of the pros and cons of different policies, and a greater perception of environmental issues. Huang et al. (2007) explored the relationship between education, policy, and renewable energy. Higher education was found to be positively associated with the awareness of the pernicious effects of fossil fuel use and, albeit less relevant, political problems deriving from a high reliance on oil imports. We expect this variable to have a positive impact on the adoption of renewable-oriented policies.

A negative relationship is thought to exist between environmental pollution and education levels: exposure to higher education facilitates the formation of social awareness and solutions to common problems (Bimonte, 2002; Dasgupta et al., 2016). It is interesting to notice how education, proxied by the ratio of total enrolment in third-level or post-secondary education (Wang \& Shao, 2019), is referred to as 'informal' regulation, given the role it plays in strengthening the environmental awareness of a society (Neves et al., 2020). An understanding of the benefits derived from environmental policies is positively connected with education for several reasons. These include a more appropriate evaluation of the benefits and costs of various regulatory measures, greater attention to environmental problems such as carbon dioxide emissions, and so on (Zarnikau, 2003). However, higher education might also promote more effective lobbying in favor of non-renewable sources, if we read such a relationship in a specular manner to the role that lack of expertise among consultants, experts and other professionals is expected to play in the adoption of renewable sources (Gan et al., 2007).

According to some scholars, the prices of conventional energies such as natural gas, oil, coal, and nuclear power might also play a role (van Ruijven \& van Vuuren, 2009). Given the degree of substitution of different energy sources, it might be expected that higher-priced traditional resources imply greater use of renewable energy (Henriques \& Sadorsky, 2008; Sadorsky, 2009a; Salim \& Rafiq, 2012; Silk \& Joutz, 1997). Nonetheless, if this is true, it must be acknowledged that such prices might influence consumption, and not the production of renewable energy, which is the focus of this article. The prices we need to consider when assessing the energy and industrial policy choices of a given country, should be the production or import prices of natural gas, oil, coal, and nuclear power to account for their effects on national renewable energy production. As is well known, such prices are not country-specific, and referring to international benchmarks and markets would not have been suitable for our purpose. 
To sum up, although all the articles noted above consider one or more of our variables, they seem to lack a comprehensive approach: a limited number of sociotechnical variables, the absence of a clear and unambiguous focus on renewable energy deployment, and an incomplete account about the existing differences across countries with respect to their institutional and socio-technical context. As a result, the very understanding of the determinants of REP remains limited (Bourcet, 2020; Can Şener et al., 2018). More specifically, it emerges that regulatory and environmental policies have a positive effect on renewable energy deployment, whereas lobbying on the part of traditional energy sources has a negative effect. Less convincing results accompany public awareness of environmental issues, which seems to be insufficient to promote a move towards renewable energy, and education, which can help only if it can support a better understanding of the advantages of green policies and renewable energy. Income levels should play a positive role, while evidence on the effects of energy imports is mixed. Overall, such effects should not overlook the importance of a country's initial conditions and the role of path dependence.

\section{Empirical analysis}

\subsection{Model specification and methodology}

Based on the literature, we constructed a model focused on the following variables: renewable electricity production (\% of total electricity output, REN); environmental policy stringency (EPS); carbon dioxide emissions (metric tons per capita, $\mathrm{CO}_{2}$ ); electricity production from oil, gas, coal and nuclear sources ( $\%$ of total, OGCN); educational attainment level of the population (in \%, EDU); gross domestic product per capita (constant 2010 US\$, GDP); and energy imports (net, \% of energy use, IMP).

As mentioned previously, REN denotes the share of renewable electricity production as a percentage of total electricity output, and is used as a proxy for REP. Many authors employ the share of renewable energy sources in electricity production as a dependent variable (Bourcet, 2020). To measure the role of regulatory constraints and policy stringency we adopt the variable EPS: it is an internationally-comparable index of the stringency of environmental regulation at the country level. Stringency represents the level to which environmental policies place an explicit or implicit price on environmentally-harmful behavior or pollution. The measure varies from 0 (not stringent) to 6 (the highest degree of stringency): it is built on the level of stringency of 14 environmental policy tools, mainly related to climate and air pollution (Botta \& Koźluk, 2014; de Serres et al., 2010). Environmental pollution and public awareness are proxied by $\mathrm{CO}_{2}$ : it measures carbon dioxide emissions generated during gas flaring, and as a result of the consumption of solid, liquid, and gas fuels. To consider private interests and lobbying, we adopt the variable OGCN. OGCN refers to electricity production from oil, gas, coal, and nuclear sources: larger consumption needs can be supplied by a combination of non-renewable and renewable energy sources. We controlled for the production of energy, expecting either a positive or negative effect on REN. OGCN might also refer to lobbying (Marques \& Fuinhas, 
Table 1 Description of variables

\begin{tabular}{lll}
\hline Variable & Definition & Source \\
\hline REN & Renewable electricity output (\% of total electricity production) & World Bank \\
EPS & Environmental Policy Stringency Index & OECD \\
GDP & GDP per capita (constant 2010 US\$) & World Bank \\
$\mathrm{CO}_{2}$ & $\mathrm{CO}_{2}$ emissions (metric tons per capita) & World Bank \\
OGCN & Electricity production from oil, gas, coal and nuclear sources (\% of total) & World Bank \\
EDU & Population 15-64 years by educational attainment level (\%) (isced 3-8) & Eurostat \\
IMP & Energy imports, net (\% of energy use) & World Bank \\
\hline
\end{tabular}

Table 2 Descriptive statistics

\begin{tabular}{lrrrr}
\hline Variable & Mean & Std. Dev. & \multicolumn{1}{l}{ Min } & Max \\
\hline REN & 19.14 & 18.94 & 0.58 & 81.06 \\
EPS & 1.85 & 0.90 & 0.35 & 4.13 \\
GDP & 32.49 & 13.97 & 5.51 & 65.43 \\
$\mathrm{CO}_{2}$ & 8.26 & 2.15 & 4.24 & 13.72 \\
OGCN & 79.25 & 19.14 & 17.72 & 99.28 \\
EDU & 64.42 & 15.68 & 19.30 & 87.60 \\
IMP & 48.92 & 30.04 & -65.69 & 90.68 \\
\hline
\end{tabular}

2011, 2012; Marques et al., 2010), which creates a potential barrier to renewable energy. EDU is a proxy for technical understanding and the level of education. It measures the educational attainment level (upper secondary, post-secondary nontertiary and tertiary education) of the population from 15 to 64 years. GDP is per capita gross domestic product, converted to international dollars using purchasing power parity rates. Data are in constant 2010 US dollars, converted from domestic currencies using 2010 official exchange rates. Finally, IMP can be considered a valuable proxy for the level of installed capacity and energy security.

The purpose of the paper is to examine the role of institutional and socio-technical variables in the production of renewable energy in 18 EU member states (Austria, Belgium, Czech Republic, Denmark, Finland, France, Germany, Greece, Hungary, Ireland, Italy, Netherlands, Poland, Portugal, Slovak Republic, Spain, Sweden, and the United Kingdom). Based on annual data from 1990 to 2015, we employed the PVAR approach, which allows us to highlight bidirectional dynamic effects and potential path dependences. Table 1 presents the variables, their definitions, and sources.

In line with Love and Zicchino (2006), the following PVAR model was used to estimate endogenous relationships among the variables described above:

$$
X_{i t}=f_{i}+\Gamma(L) X_{i t}+\varepsilon_{i t},
$$


Table 3 Unit root tests: variables in level

Table 4 Unit root tests: variables in first differences

\begin{tabular}{lccc}
\hline Variable & IPS W-t-bar & MW & $\begin{array}{l}\text { Pesaran } \\
\text { Z-t-bar }\end{array}$ \\
\hline REN & 12.635 & 13.479 & 0.611 \\
EPS & 3.742 & 10.896 & -0.164 \\
GDP & 2.541 & 16.302 & -0.924 \\
CO $_{2}$ & 4.714 & 8.048 & $-3.241^{* * *}$ \\
OGCN & 11.225 & 12.699 & -0.37 \\
EDU & 1.432 & 19.855 & 1.799 \\
IMP & -0.209 & 43.779 & -0.311 \\
\hline
\end{tabular}

$* \mathrm{p}<0.1 ; * * \mathrm{p}<0.05 ; * * * \mathrm{p}<0.01$

\begin{tabular}{lcll}
\hline Variable & IPS W-t-bar & MW & $\begin{array}{l}\text { Pesaran } \\
\text { Z-t-bar }\end{array}$ \\
\hline dREN & $-11.138^{* * *}$ & $224.079 * * *$ & $-8.791 * * *$ \\
dEPS & $-16.452 * * *$ & $204.742 * * *$ & $-5.431 * * *$ \\
dGDP & $-9.174 * * *$ & $145.072 * * *$ & $-1.546 * * *$ \\
dCO $_{2}$ & $-17.359 * * *$ & $178.240 * * *$ & $-8.835 * * *$ \\
dOGCN & $-11.883 * * *$ & $243.187 * * *$ & $-8.882^{* * *}$ \\
dEDU & $-15.690^{* * *}$ & $288.347 * * *$ & $-7.019 * * *$ \\
dIMP & $-13.026 * * *$ & $181.071 * * *$ & $-6.343 * * *$ \\
\hline$* \mathrm{p}<0.1 ; * * \mathrm{p}<0.05 ; * * * \mathrm{p}<0.01$ & &
\end{tabular}

where $X_{i t}$ is the vector of stationary indicators, $f_{i}$ is the vector of country-specific effects, $\Gamma(L)$ is a matrix whose elements are polynomial in the lag operator, and $\varepsilon_{i t}$ is the random perturbation (later $d$ denotes first difference operator). Table 2 provides the descriptive statistics.

\subsection{Testing framework}

Variables at the macroeconomic level are often non-stationary, and this may generate spurious results in the econometric analysis. In such a context, first-difference transformation can be employed to solve the problem. Therefore, we conducted various first-second unit root tests to investigate the stationarity of the indicators. Specifically, IPS tests, MW tests, and Pesaran tests were employed to analyse the order of integration of our variables, checking the null hypothesis that assumes the presence of a unit root in the panel. The results show that, at conventional levels of significance, all variables are non-stationary in levels, but stationary after the first difference transformations (see Tables 3 and 4).

To take account of cross-section interdependence, we conducted the cointegration tests introduced by Westerlund (2007). These tests are based on the null hypothesis of the absence of cointegration. None of the four tests allow us to reject the null hypothesis of absence of cointegration (see Appendix 1, Table 9). An estimation in 
first differences is therefore necessary since the variables in level are non-stationary and non-cointegrated.

The lag order selection was the final preliminary step in our analysis. Specifically, according to the econometric literature, the optimal lag length should minimize the moment model selection criteria MBIC, MAIC, MQIC proposed by Andrews and Lu (2001). Based on the three model selection criteria, a first-order PVAR was the chosen model (see Appendix 1, Table 10).

The deterministic fixed effects $f_{i}$ in Eq. (1) were removed by using the first difference transformation. As is well known, this method however may cause the so-called Nickell bias (Nickell, 1981), with the possibility of obtaining biased and inconsistent estimates using OLS (Baltagi, 2008). To overcome this difficulty, we used forward mean-differencing, also referred to as the Helmert transformation (Arellano \& Bover, 1995; Love \& Zicchino, 2006), which preserves the orthogonality between lagged regressors and transformed variables. The model may therefore be estimated using the Generalized Method of Moments (GMM) and the lagged values of the regressors can be used as instruments.

\subsection{Empirical results and discussion}

After conducting the preliminary tests, the PVAR was estimated by selecting one lag and using the GMM-style option. This guarantees more efficient estimates by replacing missing values with zero (Holtz-Eakin et al., 1988). The results are presented in Table 5.

The stability of the model was analysed and verified as the eigenvalues are strictly less than 1 (see Appendix 1, Table 11 and Fig. 2). This also shows that the employed variables are stationary (Lutkepohl, 2005). We also executed the Granger causality test which confirmed the existence of endogeneity (see Appendix 1, Table 12).

The results show that EPS does not seem to have, at least immediately, a significant impact on REN. This might be due to the strong heterogeneity across countries. If GDP rises, then REN decreases: economic growth is likely to increase the demand for energy, while renewables (especially in the past) offered only a modest

Table 5 PVAR results

\begin{tabular}{|c|c|c|c|c|c|c|c|}
\hline \multirow{2}{*}{$\begin{array}{l}\text { Independ- } \\
\text { ent vari- } \\
\text { ables }\end{array}$} & \multicolumn{7}{|c|}{ Dependent variables } \\
\hline & dREN & dEPS & dGDP & $\mathrm{dCO}_{2}$ & dOGCN & dEDU & dIMP \\
\hline dREN & $-4.470 * * *$ & $0.104 * * *$ & 0.006 & 0.041 & $4.233 * * *$ & $0.210 * * *$ & $0.984 * * *$ \\
\hline dEPS & -0.577 & 0.069 & $1.271 * * *$ & $0.897 * * *$ & -0.461 & $1.868 * * *$ & $3.151 * * *$ \\
\hline dGDP & $-1.489 * * *$ & $0.086^{* * *}$ & $0.749 * * *$ & $0.280 * * *$ & $1.342 * * *$ & $0.297 * * *$ & $1.221 * * *$ \\
\hline $\mathrm{dCO}_{2}$ & $1.231 * *$ & $-0.398 * * *$ & $0.497 * * *$ & $-0.430 * * *$ & $-1.382 * *$ & $-0.267 * *$ & $-5.971 * * *$ \\
\hline dOGCN & $-4.208 * * *$ & $0.119 * * *$ & -0.005 & $0.054 * *$ & $3.964 * * *$ & $0.224 * * *$ & $1.139 * * *$ \\
\hline dEDU & $-1.009 * * *$ & 0.007 & $0.093 * * *$ & $0.127 * * *$ & $1.083 * * *$ & $-0.123 *$ & $0.269 * *$ \\
\hline dIMP & $0.104 * *$ & 0.004 & -0.012 & 0.004 & -0.075 & $-0.060 * * *$ & $0.352 * * *$ \\
\hline
\end{tabular}

$* \mathrm{p}<0.1 ; * * \mathrm{p}<0.05 ; * * * \mathrm{p}<0.01$ 
contribution. This is also confirmed by the fact that, if GDP increases, OGCN will follow. An increase in $\mathrm{CO}_{2}$ and public awareness will promote an increase in REN. On the other hand, OGCN seems to negatively affect the transition to renewable energy. In other words, the existing energy production systems, mainly based on oil, natural gas, coal, and nuclear sources, could represent a substantial burden on the deployment of renewable energy. Our findings show that EDU significantly influences REN negatively. This does not necessarily mean that education is not important, or that it even might represent an obstacle to the energy transition. Two reasons can explain such an outcome. First, the observed countries with a higher level of education typically adopt models of production and consumption that inevitably need more energy, which means more carbon-dioxide emissions. Education (through public awareness) cannot compensate for such high levels of energy demand. In the long term, considering the correlation between the average values of EDU and $\mathrm{CO}_{2}$ for the time interval, we obtain positive values (above 0.70) except for Hungary, Sweden, and the Slovak Republic. This is in line with the literature on the effect of socio-economic and behavioral aspects on carbon dioxide emissions: education and $\mathrm{CO}_{2}$ emissions are positively correlated, but higher levels of education 'reduce' emissions when further factors are controlled for (Baiocchi et al., 2010; Büchs \& Schnepf, 2013). Secondly, despite the importance of public awareness in the transition process, stakeholders might not exert enough pressure towards renewable sources. Finally, the increase in energy imports seems to push countries towards renewable sources. If GDP increases, there is room for more stringent environmental policies. If OGCN increases, the response is usually an increase in EPS. A more vigorous environmental policy, in turn, does not slow down economic growth. Increases in GDP and OGCN lead to higher $\mathrm{CO}_{2}$ emissions, and more stringent environmental policies do not seem to guarantee an immediate decrease in $\mathrm{CO}_{2}$. Finally, IMP shows path dependence, with more virtuous countries increasing their energy security.

Table 6 shows the variance decomposition (obtained following the Cholesky decomposition using 1000 Monte Carlo simulations for 10 periods), which evaluates the relative importance of shocks in one variable on variations in other variables over time.

Table 6 Variance decomposition analysis

\begin{tabular}{|c|c|c|c|c|c|c|c|}
\hline \multirow{2}{*}{$\begin{array}{l}\text { Response vari- } \\
\text { able }\end{array}$} & \multicolumn{7}{|c|}{ Impulse variable } \\
\hline & dREN (\%) & dEPS $(\%)$ & $\mathrm{dGDP}(\%)$ & $\mathrm{dCO}_{2}(\%)$ & dOGCN (\%) & $\mathrm{dEDU}(\%)$ & $\operatorname{dIMP}(\%)$ \\
\hline dREN & 68.83 & 1.54 & 2.79 & 3.29 & 20.48 & 2.73 & 0.33 \\
\hline dEPS & 8.36 & 67.37 & 0.50 & 17.10 & 6.27 & 0.25 & 0.15 \\
\hline dGDP & 4.45 & 8.49 & 83.49 & 1.70 & 0.69 & 1.03 & 0.15 \\
\hline $\mathrm{dCO}_{2}$ & 16.49 & 11.68 & 27.34 & 38.43 & 2.16 & 3.76 & 0.14 \\
\hline $\mathrm{dOGCN}$ & 68.09 & 2.00 & 1.93 & 3.70 & 20.78 & 3.30 & 0.20 \\
\hline $\mathrm{dEDU}$ & 0.87 & 12.04 & 4.55 & 3.11 & 3.52 & 73.73 & 2.18 \\
\hline dIMP & 12.34 & 11.40 & 0.87 & 18.87 & 7.83 & 0.65 & 48.04 \\
\hline
\end{tabular}

Variation in response variable explained by the impulse variables in the columns (10 periods ahead) 


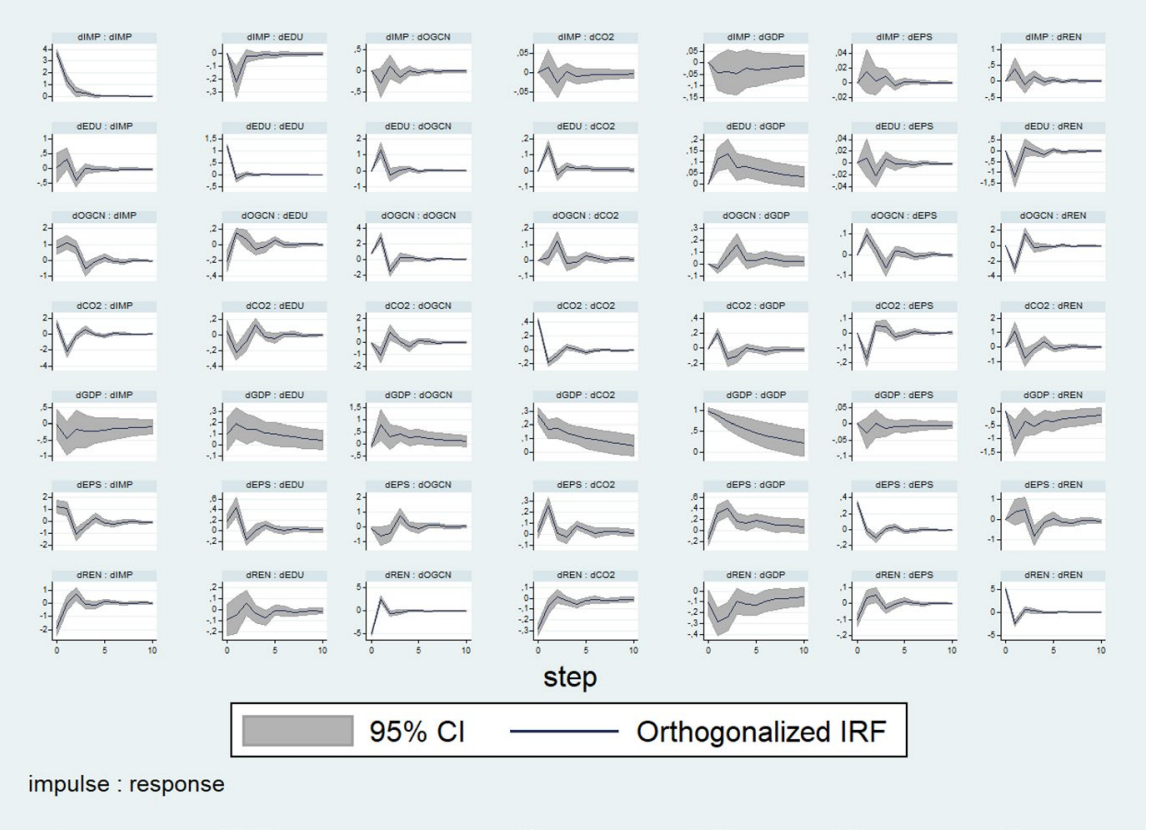

Fig. 1 Impulse response analysis

The table highlights that usually each variable is mainly influenced by its lag. Specifically, REN is mainly determined by OGCN (20.48\%), $\mathrm{CO}_{2}(3.29 \%)$, and GDP $(2.79 \%)$ on average during a 10 -year period, while OGCN is mainly influenced by shocks in REN (68.09\%). An increase in REN could impact on the production of energy from traditional sources at an early stage, and this can negatively affect REN in the future, although this effect is gradual and indirect.

Figure 1 illustrates the impulse response functions, which describe the evolution of a variable of interest along the time horizon after a shock in another variable.

When one positive unit shock is applied to one variable in the current period, the response variable usually exhibits a remarkable response in the early phases, followed by a slight fluctuation. Interestingly, when a positive shock is exerted on GDP or OGCN in the present period, REN exhibits negative responses in early phases.

\subsection{High and low energy importers}

The European Green Deal, in setting objectives in terms of renewable sources development (even for those countries that are rich in traditional energy sources), stresses that countries move from different starting points and are likely to need different strategies. Our intention is to consider these diverse initial conditions. In this context, some scholars have advanced the hypothesis that there exists a relationship between energy security and REP (Chien \& Hu, 2008; Gan et al., 2007; Marques \& Fuinhas, 2011). Others have suggested that in order to appreciate a country's efforts 
Table 7 PVAR results-panel A

\begin{tabular}{|c|c|c|c|c|c|c|}
\hline \multirow{2}{*}{$\begin{array}{l}\text { Independent } \\
\text { variables }\end{array}$} & \multicolumn{6}{|c|}{ Dependent variables } \\
\hline & dREN & dEPS & dGDP & $\mathrm{dCO}_{2}$ & $\mathrm{dOGCN}$ & $\mathrm{dEDU}$ \\
\hline dREN & $3.759 * * *$ & $-0.200 * * *$ & $0.131 * * *$ & -0.103 & $-4.053 * * *$ & $0.213 * * *$ \\
\hline dEPS & $26.516^{* * *}$ & $-0.247 * * *$ & $1.537 * * *$ & 0.154 & $-26.414 * * *$ & $2.502 * * *$ \\
\hline dGDP & $3.287 * * *$ & -0.001 & $0.645 * * *$ & $0.194 * * *$ & $-3.236^{* * *}$ & $0.529 * * *$ \\
\hline $\mathrm{dCO}_{2}$ & $-11.504 * * *$ & 0.084 & $1.008 * * *$ & 0.158 & $11.430 * * *$ & $-1.154 * * *$ \\
\hline $\mathrm{dOGCN}$ & $4.423 * * *$ & $-0.199 * * *$ & $0.095 * *$ & $-0.118 *$ & $-4.716 * * *$ & $0.240 * * *$ \\
\hline $\mathrm{dEDU}$ & 0.079 & $-0.026 *$ & 0.014 & $0.047 * * *$ & -0.089 & $0.329 * * *$ \\
\hline
\end{tabular}

$* \mathrm{p}<0.1 ; * * \mathrm{p}<0.05 ; * * * \mathrm{p}<0.01$

Table 8 PVAR results-panel B

\begin{tabular}{|c|c|c|c|c|c|c|}
\hline \multirow{2}{*}{$\begin{array}{l}\text { Independent } \\
\text { variables }\end{array}$} & \multicolumn{6}{|c|}{ Dependent variables } \\
\hline & dREN & dEPS & dGDP & $\mathrm{dCO}_{2}$ & dOGCN & $\mathrm{dEDU}$ \\
\hline dREN & $-0.380 * *$ & $0.015^{* *}$ & $-0.168 * * *$ & $-0.189 * * *$ & $0.503^{* * * *}$ & $0.234 * * *$ \\
\hline dEPS & $-8.525^{* * *}$ & $-0.150 * * *$ & $1.584 * * *$ & $0.940 * * *$ & $7.530 * * *$ & $0.666^{* * * *}$ \\
\hline dGDP & $-1.804 * * *$ & 0.018 & $0.633 * * *$ & $0.147 * * *$ & $1.564 * * *$ & $0.163 * * *$ \\
\hline $\mathrm{dCO}_{2}$ & $2.953 * * *$ & $-0.217 * * *$ & $0.279 * * *$ & $-0.486^{* * *}$ & $-2.771 * * *$ & $-0.357 * * *$ \\
\hline $\mathrm{dOGCN}$ & $-0.548 * * *$ & $0.027 * * *$ & $-0.124 * * *$ & $-0.120 * * *$ & $0.592 * * *$ & $0.223 * * *$ \\
\hline dEDU & $-0.309 * *$ & 0.010 & $0.106^{* * *}$ & $0.118 * * *$ & $0.490 * * *$ & $-0.300 * * *$ \\
\hline
\end{tabular}

$* \mathrm{p}<0.1 ; * * \mathrm{p}<0.05 ; * * * \mathrm{p}<0.01$

towards REP, it might be useful to consider the actual level of installed capacity (Bourcet, 2020). We decided to split the sample into two groups, based on recent energy imports; in fact, this reflects the (current) different stages of countries in terms of levels of installed capacity and energy security.

We examine the role of institutional and socio-technical variables in the production of renewable energy for two panels (A and B) of 10 and 8 EU member states that are, respectively, high energy importers with a share from third countries higher than 50\% on average over the last five years (Austria, Belgium, Germany, Greece, Hungary, Ireland, Italy, Portugal, Slovak Republic, and Spain) and low energy importers with a share less than 50\% on average (Czech Republic, Denmark, Finland, France, Netherlands, Poland, Sweden, and United Kingdom). The choice is rational and does not create any distortion for the analysis: the two groups would have been substantially the same even if we had used the average percentage of energy imports over the entire period under consideration (with the only exception being Finland, which would have switched from one panel to the other). Similarly, if we had used a different threshold such as the median IMP, over the past 5 years $(56.77 \%)$ or for the entire period under consideration $(58.34 \%)$, we would have obtained a similar split: only Hungary would have moved from one sub-sample to the other, based on its average IMP (also in this case calculated over the last 5 years or over the entire period). Moreover, based 
on Table 2, the negative minimum value of IMP means that some countries have been net exporters for some years. Specifically, UK was mostly a net exporter in the 1990s, while Denmark was a net exporter in the 2000s.

We again employed the PVAR approach. To limit the length of the analysis we opted to include in Appendix 2 the results of some preliminary analyses: the descriptive statistics (see Tables 13 and 14), the unit root tests for both variables in level and in first differences (see Tables 15, 16, 17, and 18), the cointegration tests (see Tables 19 and 20), and the lag order selection analyses (see Tables 21 and 22).

All coefficients resulting from the PVAR analyses conducted over both Panels A and B are as shown in Tables 7 and 8.

For the first group of member states (panel A, high energy importers), the results show that policy stringency has positive direct effects on REN. Based on the coefficients, an increase in EPS would also generate a decrease in OGCN. The reduction in OGCN, in turn, does not seem to exert a reduction in REN, probably due to its relatively low weight in the case of high energy importers. This finding does not necessarily mean that OGCN is irrelevant for REN, but rather that the effects of traditional energy industries are not large enough to affect REN. As expected, the analysis shows positive bidirectional casual relationships between GDP and REN. A decrease in $\mathrm{CO}_{2}$ also seems to generate an increase in REN. Furthermore, a dynamic effect (path dependence) is evident, demonstrating that the input of GDP and REN observed in previous periods affects that in the present period. If policy stringency, together with income, brings an increase in REN, this will mitigate policy stringency in the long run.

For the second group of countries (panel B, low energy importers), the results show that policy stringency has a negative effect on REN, at least immediately. OGCN negatively affects the transition to renewable energy. As expected, this implies that existing energy production systems, which for electricity are mainly based on oil, natural gas, coal, and nuclear sources, could place a substantial burden on the deployment of renewable energy. Therefore, in places where core energy infrastructures still depend heavily on non-renewable sources, the traditional sector represents the reference point governments should focus upon in their efforts to promote REN. Fostering a renewable-energy economy will probably require a longer period. As expected, an increase in $\mathrm{CO}_{2}$ and public awareness will promote an increase in REN. Furthermore, an increase in REN could generate a positive reaction in terms of OGCN, and lobbying could once again slow the transition to a renewable-based economy.

Furthermore, the results show the existence of dynamic effects in terms of GDP and OGCN. As expected, there was a negative causal relationship between $\mathrm{REN}$ and $\mathrm{CO}_{2}$ for both groups. This implies that the transition to renewable energy should mitigate carbon dioxide emissions and their negative consequences in terms of both climate change and global warming. Finally, our findings show that EDU does not significantly influence REN in the case of panel A, but influences it negatively in the case of panel B.

Similar results have been obtained both by splitting the sample on the median IMP, and by excluding from the analysis those countries that in the past were net exporters.

Appendix 2 also contains the results of the stability analyses (see Tables 23 and 24, and Figs. 3 and 4), the Granger causality tests (see Tables 25 and 26), the 
variance decomposition analysis (see Tables 27 and 28), and the impulse response analyses (see Figs. 5 and 6).

\section{Conclusions and policy implications}

This article contributes to the debate on the determinants of REP, focusing on the role that institutional and socio-technical aspects play, an aspect which has been considered only partially in the literature (Bourcet, 2020). We employed a PVAR model in first differences to test the complex dynamic relationships among REP, policy stringency, public awareness, lobbying, and education, controlling for per capita income and share of energy imports, for 18 European Union countries.

The results show that EPS does not impact significantly on REN, at least in the short run. This is probably due to the strong heterogeneity among countries, which are different in terms of the level of installed capacity and energy security. An increase in GDP has a negative effect on REN: economic growth is related to an increase in energy demand, and the development of renewable energy sources is often not enough to meet this higher demand. This seems to be confirmed by the fact that an increase in GDP is followed by an increase in energy consumption from traditional energy sources (OGCN increases, with further negative repercussions on REN).

An increase in $\mathrm{CO}_{2}$ and public awareness would promote an increase in REN. EDU would impact negatively on REN. This does not mean that education may represent a barrier to the transition to REP. Countries with higher levels of education usually adopt models of production and consumption that inevitably need more energy; as already highlighted, a higher need for energy has often been met through a more vigorous use of traditional sources, especially in past decades. Education cannot compensate for such high levels of energy demand. Moreover, despite the importance of public awareness in the conversion process, stakeholders might not exert enough pressure to encourage a move towards renewable sources.

According to the recent European Green Deal which emphasizes that countries starting from different points need different strategies, we split the entire sample into two panels (A and B) of 10 and $8 \mathrm{EU}$ member states that currently are high and low energy importers, respectively. This allowed us to consider the starting points for countries that are different in terms of level of installed capacity and energy security.

With regard to panel A, estimations show that policy stringency has positive direct effects on REP and should be prioritized to promote the transition to a renewable-energy-based economy. This finding is in line with the existing literature concerning the need for public intervention to promote renewable energy use. As a result, the existence of support policies is expected to have a positive influence on REP. Based on the coefficients, an increase in stringency will generate a decrease in lobbying: these results, although predictable, have rarely been highlighted in the literature (Bourcet, 2020). As expected, the analysis shows the existence of positive bidirectional casual relationships between income and REP. 
Because stringency positively affects income, policymakers should have more chance to promote renewable sources. A decrease in $\mathrm{CO}_{2}$ emissions also seems to generate an increase in REP. The results suggest that if policy stringency, together with public awareness and income, leads to an increase in REP, this will mitigate policy stringency in the long run. Therefore, to support REP, policy efforts must be well established and consistently preserved if there are increasing returns to exploit.

For panel B, the results show that lobbying negatively affects the transition to REP. As expected, this implies that existing energy production systems, primarily based on oil, natural gas, coal, and nuclear sources for the generation of electricity, could represent a substantial burden on the deployment of renewable energy. Fostering a renewable-energy economy will probably require a longer period. If governments decide to continue to invest in traditional sources, this might represent a further obstacle to the growth of REP. Furthermore, an increase in REP could generate a positive reaction in terms of lobbying, and lobbying could once again slow the transition to a renewable-based economy. In this case, to promote the transition to REP, priority should be given to social efforts to decrease the share of traditional energy sources. The analysis shows the existence of dynamic effects in terms of income and lobbying. Given the negative effects of income and lobbying on REP, policymakers should increase their efforts to reduce the proportion of electricity generated from non-renewable energy, and initiate an ambitious process that will ensure progress in the transition to REP in the long term. In other words, the efforts should be followed by policies that ensure a constant commitment to renewable sources (inducing eco-friendly activities; developing market conditions that can create a massive demand for renewable energy use and renewable energy technologies and products).

As expected, there was a negative causal relationship between REP and $\mathrm{CO}_{2}$ emissions for both the groups. Informal pressures come mainly from the public and relate to social norms, and to values and expectations that must be respected. The public plays a significant role by providing awareness of REP and influencing the policies and procedures of other actors. On the contrary, the relationship could also reflect society's apathy towards environmental problems.

The analysis shows that countries starting from different initial conditions in terms of installed capacity, need different transition policies. Data show that historically high/low energy importing countries have remained such over the years: the starting point becomes a country-specific condition for the transition process towards a greener economy. The split between the two panels is substantially independent on the type of threshold used (IMP equal to $50 \%$ or its median value) and on the period observed-whole or limited to the last 5 years. To sum up, policymakers should direct their efforts in different directions, bearing in mind two important aspects. First, there are strong divergences that derive from the countries' initial starting points because of differing economic and sociopolitical contexts. More feasible action is needed, especially for those countries that are low importers (this may represent an obstacle with regard to initiating a more vigorous transition to renewable energy). Secondly, policy efforts toward REP need continuity as REP is a dynamic process with time lags. National 
governments should increase the level of education and public pressure by working with schools, training institutions, and universities to prepare the stakeholders who will ensure continuity in the transition toward renewable energy. In short, policymakers should have the vision and patience to understand how yesterday's choices affect today's results.

Although our focus has been on the EU, it might be interesting to replicate the exercise with regard to US federal states to appreciate the impact that socio-technical drivers produce on energy transition, net of the policies adopted over time. As seen above, some analyses have been proposed for the US, all emphasizing the positive effects that policies and regulation have on renewable energy, but our model would allow us to appreciate the extent to which socio-technical aspects prop up the policies adopted by state governments.

\section{Appendix 1}

See Tables 9, 10, 11, 12 and Fig. 2.

Table 9 Cointegration tests

\begin{tabular}{lll}
\hline Statistic & Value & p-value \\
\hline $\mathrm{G}_{\tau}$ & -0.652 & 1.000 \\
$\mathrm{G}_{\alpha}$ & -0.819 & 1.000 \\
$\mathrm{P}_{\tau}$ & -2.823 & 0.920 \\
$\mathrm{P}_{\alpha}$ & -0.963 & 0.940 \\
\hline
\end{tabular}

p-value are robust critical values obtained through bootstrapping with 100 replications

Table 10 Lag order selection criteria

\begin{tabular}{llll}
\hline Lag & MBIC & MAIC & MQIC \\
\hline 1 & -401.261 & -61.391 & -198.380 \\
2 & -214.099 & -44.164 & -112.659 \\
\hline
\end{tabular}

Table 11 Eigenvalue stability condition

\begin{tabular}{lcc}
\hline Eigenvalue & & \\
\hline Real & Imaginary & Modulus \\
\hline 0.860 & 0.000 & 0.860 \\
-0.126 & 0.586 & 0.600 \\
-0.126 & -0.586 & 0.600 \\
-0.494 & 0.000 & 0.494 \\
0.344 & 0.000 & 0.344 \\
-0.174 & -0.161 & 0.237 \\
\hline
\end{tabular}


Table 12 Granger causality test

\begin{tabular}{|c|c|c|c|}
\hline Equation Variable & Excluded Variables & Chi2 & $\mathrm{p}$ value \\
\hline \multirow[t]{7}{*}{ dREN } & dEPS & 0.773 & 0.379 \\
\hline & dGDP & 46.827 & 0.000 \\
\hline & $\mathrm{dCO}_{2}$ & 4.286 & 0.038 \\
\hline & dOGCN & 123.386 & 0.000 \\
\hline & dEDU & 24.778 & 0.000 \\
\hline & dIMP & 4.371 & 0.037 \\
\hline & ALL & 160.018 & 0.000 \\
\hline \multirow[t]{7}{*}{ dEPS } & dREN & 37.300 & 0.000 \\
\hline & dGDP & 18.627 & 0.000 \\
\hline & $\mathrm{dCO}_{2}$ & 55.335 & 0.000 \\
\hline & dOGCN & 43.451 & 0.000 \\
\hline & dEDU & 0.308 & 0.579 \\
\hline & dIMP & 1.105 & 0.293 \\
\hline & ALL & 80.288 & 0.000 \\
\hline \multirow[t]{7}{*}{ dGDP } & dREN & 0.064 & 0.801 \\
\hline & dEPS & 79.738 & 0.000 \\
\hline & $\mathrm{dCO}_{2}$ & 45.498 & 0.000 \\
\hline & dOGCN & 0.042 & 0.837 \\
\hline & dEDU & 18.392 & 0.000 \\
\hline & dIMP & 1.238 & 0.266 \\
\hline & ALL & 224.276 & 0.000 \\
\hline \multirow[t]{7}{*}{$\mathrm{dCO}_{2}$} & dREN & 2.018 & 0.155 \\
\hline & dEPS & 103.237 & 0.000 \\
\hline & dGDP & 64.674 & 0.000 \\
\hline & dOGCN & 3.525 & 0.060 \\
\hline & dEDU & 73.701 & 0.000 \\
\hline & dIMP & 0.361 & 0.548 \\
\hline & ALL & 203.351 & 0.000 \\
\hline \multirow[t]{7}{*}{ dOGCN } & dREN & 148.024 & 0.000 \\
\hline & dEPS & 0.431 & 0.511 \\
\hline & dGDP & 35.738 & 0.000 \\
\hline & $\mathrm{dCO}_{2}$ & 5.868 & 0.015 \\
\hline & $\mathrm{dEDU}$ & 28.630 & 0.000 \\
\hline & dIMP & 2.469 & 0.116 \\
\hline & ALL & 180.992 & 0.000 \\
\hline \multirow[t]{7}{*}{ dEDU } & dREN & 35.446 & 0.000 \\
\hline & dEPS & 55.309 & 0.000 \\
\hline & dGDP & 20.679 & 0.000 \\
\hline & $\mathrm{dCO}_{2}$ & 6.411 & 0.011 \\
\hline & dOGCN & 50.939 & 0.000 \\
\hline & dIMP & 13.596 & 0.000 \\
\hline & ALL & 117.404 & 0.000 \\
\hline
\end{tabular}


Table 12 (continued)

\begin{tabular}{llll}
\hline Equation Variable & Excluded Variables & \multicolumn{1}{l}{ Chi2 } & p value \\
\hline dIMP & dREN & 20.346 & 0.000 \\
& dEPS & 26.963 & 0.000 \\
& dGDP & 34.910 & 0.000 \\
& dCO $_{2}$ & 87.331 & 0.000 \\
& dOGCN & 28.371 & 0.000 \\
& dEDU & 5.025 & 0.025 \\
& ALL & 164.845 & 0.000 \\
\hline
\end{tabular}

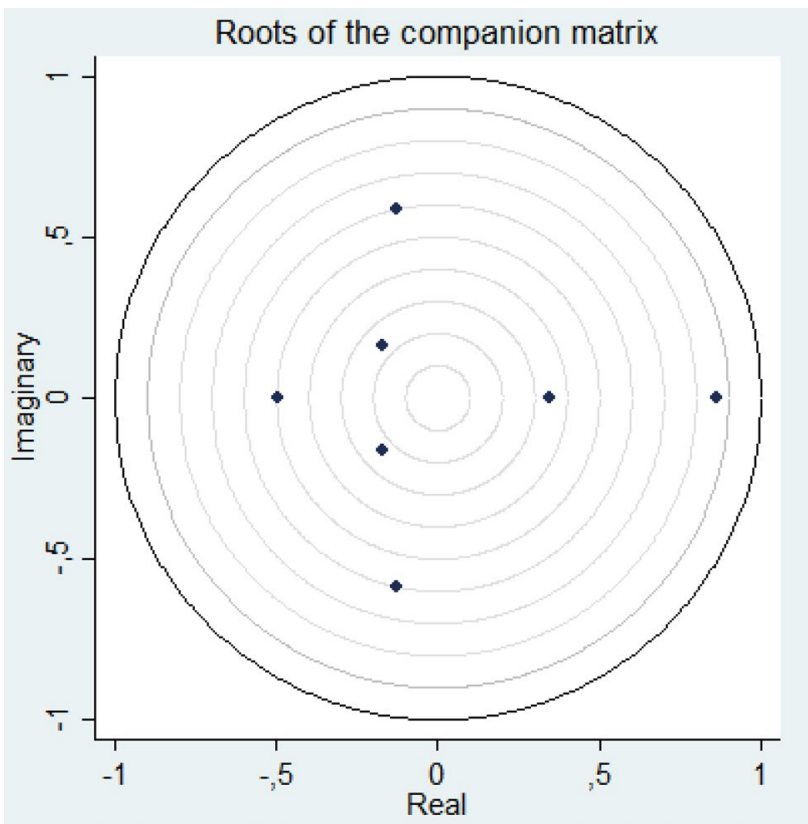

Fig. 2 Roots of the companion matrix

\section{Appendix 2}

See Tables 13, 14, 15, 16, 17, 18, 19, 20, 21, 22, 23, 24, 25, 26, 27, 28 and Figs. 3, 4, 5, 6 . 
Table 13 Descriptive statistics-panel A

Table 14 Descriptive statistics-panel B

Table 15 Unit root tests: variables in level—panel A

Table 16 Unit root tests: variables in level-panel B

\begin{tabular}{lrrrr}
\hline Variable & Mean & Std. Dev & Min & Max \\
\hline REN & 20.63 & 19.98 & 0.58 & 81.06 \\
EPS & 1.76 & 0.81 & 0.35 & 3.33 \\
GDP & 29.71 & 12.20 & 7.71 & 65.43 \\
$\mathrm{CO}_{2}$ & 7.74 & 1.87 & 4.24 & 11.62 \\
$\mathrm{OGCN}_{\text {EDU }}$ & 77.92 & 19.66 & 17.72 & 99.28 \\
\hline
\end{tabular}

\begin{tabular}{lrrrr}
\hline Variable & Mean & Std. Dev & Min & Max \\
\hline REN & 17.28 & 17.42 & 1.10 & 65.51 \\
EPS & 1.97 & 1.00 & 0.54 & 4.13 \\
GDP & 35.92 & 15.23 & 5.51 & 61.18 \\
$\mathrm{CO}_{2}$ & 8.91 & 2.31 & 4.48 & 13.72 \\
OGCN & 80.91 & 18.39 & 31.90 & 98.75 \\
EDU & 71.82 & 8.26 & 47.50 & 87.60 \\
\hline
\end{tabular}

\begin{tabular}{llrr}
\hline Variable & IPS W-t-bar & MW & $\begin{array}{l}\text { Pesaran } \\
\text { Z-t-bar }\end{array}$ \\
\hline REN & 9.660 & 10.449 & 1.430 \\
EPS & 2.436 & 8.536 & 1.121 \\
$\mathrm{GDP}$ & 1.859 & 8.815 & -0.186 \\
$\mathrm{CO}_{2}$ & 3.843 & 3.406 & -1.255 \\
$\mathrm{OGCN}$ & 8.552 & 9.471 & 0.495 \\
EDU & 0.993 & 10.261 & -0.915 \\
\hline
\end{tabular}

${ }^{*} \mathrm{p}<0.1 ; * * \mathrm{p}<0.05 ; * * * \mathrm{p}<0.01$

\begin{tabular}{llcc}
\hline Variable & IPS W-t-bar & MW & $\begin{array}{l}\text { Pesaran } \\
\text { Z-t-bar }\end{array}$ \\
\hline \multicolumn{1}{c}{ REN } & 8.155 & 3.030 & 2.757 \\
$\mathrm{EPS}$ & 2.892 & 2.360 & $-1.519^{*}$ \\
$\mathrm{GDP}$ & 1.733 & 7.487 & 0.013 \\
$\mathrm{CO}_{2}$ & 2.771 & 4.642 & $-1.661 * *$ \\
$\mathrm{OGCN}^{2}$ & 7.277 & 3.228 & 2.215 \\
$\mathrm{EDU}$ & 1.037 & 9.595 & 1.163 \\
\hline${ }^{*} \mathrm{p}<0.1 ; * * \mathrm{p}<0.05 ; * * * \mathrm{p}<0.01$ & &
\end{tabular}


Table 17 Unit root tests: variables in first differencespanel A

Table 18 Unit root tests: variables in first differencespanel B

Table 19 Cointegration testspanel A

Table 20 Cointegration testspanel B

\begin{tabular}{lcrl}
\hline Variable & IPS W-t-bar & MW & $\begin{array}{l}\text { Pesaran } \\
\text { Z-t-bar }\end{array}$ \\
\hline dREN & $-8.489 * * *$ & $133.825 * * *$ & $-3.708 * * *$ \\
dEPS & $-10.938 * * *$ & $105.490 * * *$ & $-3.254 * * *$ \\
dGDP & $-6.0277 * * *$ & $82.309 * * *$ & -0.359 \\
$\mathrm{dCO}_{2}$ & $-10.861 * * *$ & $75.727 * * *$ & $-6.921 * * *$ \\
$\mathrm{dOGCN}$ & $-8.776 * * *$ & $135.399 * * *$ & $-3.874 * * *$ \\
$\mathrm{dEDU}$ & $-10.835 * * *$ & $190.356 * * *$ & $-4.912 * * *$ \\
\hline$* \mathrm{p}<0.1 ; * * \mathrm{p}<0.05 ; * * * \mathrm{p}<0.01$ & &
\end{tabular}

\begin{tabular}{lcrl}
\hline Variable & IPS W-t-bar & MW & $\begin{array}{l}\text { Pesaran } \\
\text { Z-t-bar }\end{array}$ \\
\hline dREN & $-7.216^{* * *}$ & $90.254 * * *$ & $-3.432 * * *$ \\
dEPS & $-12.453 * * *$ & $99.252^{* * * *}$ & $-5.722 * * *$ \\
dGDP & $-7.032 * * *$ & $62.763 * * *$ & $-1.858^{* *}$ \\
$\mathrm{dCO}_{2}$ & $-13.891 * * *$ & $102.513 * * *$ & $-6.441 * * *$ \\
$\mathrm{dOGCN}$ & $-8.014 * * *$ & $107.788^{* * *}$ & $-4.016^{* * *}$ \\
$\mathrm{dEDU}$ & $-11.420 * * *$ & $97.991 * * *$ & $-6.858^{* * *}$ \\
\hline
\end{tabular}

$* \mathrm{p}<0.1 ; * * \mathrm{p}<0.05 ; * * * \mathrm{p}<0.01$

\begin{tabular}{lll}
\hline Statistic & Value & p-value \\
\hline $\mathrm{G}_{\tau}$ & -0.536 & 1.000 \\
$\mathrm{G}_{\alpha}$ & -0.69 & 1.000 \\
$\mathrm{P}_{\tau}$ & -1.06 & 0.950 \\
$\mathrm{P}_{\alpha}$ & -0.151 & 0.970 \\
\hline
\end{tabular}

p-value are robust critical values obtained through bootstrapping with 100 replications

\begin{tabular}{lll}
\hline Statistic & Value & p-value \\
\hline $\mathrm{G}_{\tau}$ & -0.466 & 0.990 \\
$\mathrm{G}_{\alpha}$ & -0.296 & 1.000 \\
$\mathrm{P}_{\tau}$ & -1.447 & 0.940 \\
$\mathrm{P}_{\alpha}$ & -0.684 & 0.930 \\
\hline
\end{tabular}

p-value are robust critical values obtained through bootstrapping with 100 replications 
Table 21 Lag order selection criteria-panel A

Table 22 Lag order selection criteria-panel B

Table 23 Eigenvalue stability condition-panel A

Table 24 Eigenvalue stability condition-panel B

\begin{tabular}{llll}
\hline Lag & MBIC & MAIC & \multicolumn{1}{l}{ MQIC } \\
\hline 1 & -266.807 & -59.245 & -143.589 \\
2 & -128.755 & -24.974 & -67.146 \\
\hline
\end{tabular}

\begin{tabular}{llll}
\hline Lag & MBIC & MAIC & \multicolumn{1}{l}{ MQIC } \\
\hline 1 & -260.540 & -77.417 & -151.622 \\
2 & -114.614 & -27.033 & -62.523 \\
\hline
\end{tabular}

Eigenvalue

\begin{tabular}{lll}
\hline Real & Imaginary & Modulus \\
\hline 0.945 & 0.000 & 0.945 \\
-0.356 & 0.298 & 0.464 \\
-0.356 & -0.298 & 0.464 \\
-0.352 & 0.000 & 0.352 \\
0.181 & 0.000 & 0.181 \\
-0.136 & 0.000 & 0.136 \\
\hline
\end{tabular}

\begin{tabular}{lcc}
\hline Eigenvalue & & \\
\hline Real & Imaginary & Modulus \\
\hline 0.755 & 0.000 & 0.755 \\
-0.461 & 0.000 & 0.461 \\
-0.060 & -0.455 & 0.459 \\
-0.060 & 0.455 & 0.459 \\
-0.132 & -0.116 & 0.176 \\
-0.132 & 0.116 & 0.176 \\
\hline
\end{tabular}


Table 25 Granger causality test-panel A

\begin{tabular}{|c|c|c|c|}
\hline Equation variable & Excluded variables & Chi2 & $\mathrm{p}$ value \\
\hline \multirow[t]{6}{*}{ dREN } & dEPS & 26.340 & 0.000 \\
\hline & dGDP & 8.872 & 0.003 \\
\hline & $\mathrm{dCO}_{2}$ & 12.058 & 0.001 \\
\hline & dOGCN & 20.169 & 0.000 \\
\hline & dEDU & 0.022 & 0.883 \\
\hline & ALL & 41.662 & 0.000 \\
\hline \multirow[t]{6}{*}{ dEPS } & dREN & 31.785 & 0.000 \\
\hline & dGDP & 0.002 & 0.961 \\
\hline & $\mathrm{dCO}_{2}$ & 2.056 & 0.152 \\
\hline & dOGCN & 30.939 & 0.000 \\
\hline & dEDU & 3.650 & 0.056 \\
\hline & ALL & 45.037 & 0.000 \\
\hline \multirow[t]{6}{*}{ dGDP } & dREN & 10.672 & 0.001 \\
\hline & dEPS & 48.417 & 0.000 \\
\hline & $\mathrm{dCO}_{2}$ & 16.282 & 0.000 \\
\hline & $\mathrm{dOGCN}$ & 5.648 & 0.017 \\
\hline & dEDU & 0.185 & 0.667 \\
\hline & ALL & 60.787 & 0.000 \\
\hline \multirow[t]{6}{*}{$\mathrm{dCO}_{2}$} & dREN & 2.083 & 0.149 \\
\hline & dEPS & 2.656 & 0.103 \\
\hline & dGDP & 32.588 & 0.000 \\
\hline & dOGCN & 2.710 & 0.100 \\
\hline & $\mathrm{dEDU}$ & 7.417 & 0.006 \\
\hline & ALL & 97.506 & 0.000 \\
\hline \multirow[t]{6}{*}{ dOGCN } & dREN & 16.641 & 0.000 \\
\hline & dEPS & 26.304 & 0.000 \\
\hline & dGDP & 8.648 & 0.003 \\
\hline & $\mathrm{dCO}_{2}$ & 11.991 & 0.001 \\
\hline & $\mathrm{dEDU}$ & 0.027 & 0.869 \\
\hline & ALL & 40.769 & 0.000 \\
\hline \multirow[t]{6}{*}{ dEDU } & dREN & 7.369 & 0.007 \\
\hline & dEPS & 35.266 & 0.000 \\
\hline & dGDP & 21.782 & 0.000 \\
\hline & $\mathrm{dCO}_{2}$ & 9.286 & 0.002 \\
\hline & dOGCN & 9.482 & 0.002 \\
\hline & ALL & 46.319 & 0.000 \\
\hline
\end{tabular}


Table 26 Granger causality test-panel B

\begin{tabular}{|c|c|c|c|}
\hline Equation variable & Excluded variables & Chi2 & $\mathrm{p}$ value \\
\hline \multirow[t]{6}{*}{ dREN } & dEPS & 82.194 & 0.000 \\
\hline & dGDP & 77.824 & 0.000 \\
\hline & $\mathrm{dCO}_{2}$ & 52.848 & 0.000 \\
\hline & $\mathrm{dOGCN}$ & 13.614 & 0.000 \\
\hline & dEDU & 5.323 & 0.021 \\
\hline & ALL & 167.613 & 0.000 \\
\hline \multirow[t]{6}{*}{ dEPS } & dREN & 3.276 & 0.070 \\
\hline & dGDP & 1.323 & 0.250 \\
\hline & $\mathrm{dCO}_{2}$ & 102.414 & 0.000 \\
\hline & dOGCN & 10.419 & 0.001 \\
\hline & dEDU & 1.715 & 0.190 \\
\hline & ALL & 152.624 & 0.000 \\
\hline \multirow[t]{6}{*}{ dGDP } & dREN & 26.495 & 0.000 \\
\hline & dEPS & 96.287 & 0.000 \\
\hline & $\mathrm{dCO}_{2}$ & 17.812 & 0.000 \\
\hline & $\mathrm{dOGCN}$ & 12.767 & 0.000 \\
\hline & dEDU & 28.473 & 0.000 \\
\hline & ALL & 268.514 & 0.000 \\
\hline \multirow[t]{6}{*}{$\mathrm{dCO}_{2}$} & dREN & 46.566 & 0.000 \\
\hline & dEPS & 89.081 & 0.000 \\
\hline & dGDP & 28.202 & 0.000 \\
\hline & $\mathrm{dOGCN}$ & 19.274 & 0.000 \\
\hline & dEDU & 76.066 & 0.000 \\
\hline & ALL & 566.768 & 0.000 \\
\hline \multirow[t]{6}{*}{ dOGCN } & dREN & 11.613 & 0.001 \\
\hline & dEPS & 82.795 & 0.000 \\
\hline & dGDP & 77.447 & 0.000 \\
\hline & $\mathrm{dCO}_{2}$ & 65.287 & 0.000 \\
\hline & $\mathrm{dEDU}$ & 16.727 & 0.000 \\
\hline & ALL & 196.342 & 0.000 \\
\hline \multirow[t]{6}{*}{ dEDU } & dREN & 84.425 & 0.000 \\
\hline & dEPS & 23.436 & 0.000 \\
\hline & dGDP & 13.619 & 0.000 \\
\hline & $\mathrm{dCO}_{2}$ & 31.347 & 0.000 \\
\hline & dOGCN & 97.284 & 0.000 \\
\hline & ALL & 225.449 & 0.000 \\
\hline
\end{tabular}


Table 27 Variance decomposition analysis_-panel A

\begin{tabular}{lcccccc}
\hline Response variable & \multicolumn{5}{l}{ Impulse variable } \\
\cline { 2 - 7 } & dREN $(\%)$ & dEPS $(\%)$ & dGDP $(\%)$ & dCO $_{2}(\%)$ & dOGCN $(\%)$ & dEDU (\%) \\
\hline dREN & 53.48 & 25.40 & 0.39 & 11.33 & 8.25 & 1.14 \\
dEPS & 4.96 & 83.53 & 0.25 & 1.50 & 8.65 & 1.10 \\
$\mathrm{dGDP}$ & 0.29 & 7.17 & 86.72 & 5.23 & 0.55 & 0.04 \\
$\mathrm{dCO}_{2}$ & 9.26 & 5.81 & 53.75 & 28.34 & 1.87 & 0.96 \\
$\mathrm{dOGCN}^{\mathrm{dEDU}}$ & 53.37 & 25.15 & 0.41 & 11.26 & 8.69 & 1.14 \\
\hline
\end{tabular}

Variation in response variable explained by the impulse variables in the columns (10 periods ahead)

Table 28 Variance decomposition analysis-panel B

\begin{tabular}{lcccccc}
\hline Response variable & \multicolumn{5}{l}{ Impulse variable } \\
\cline { 2 - 7 } & $\mathrm{dREN}(\%)$ & $\mathrm{dEPS}(\%)$ & $\mathrm{dGDP}(\%)$ & $\mathrm{dCO}_{2}(\%)$ & $\mathrm{dOGCN}(\%)$ & $\mathrm{dEDU}(\%)$ \\
\hline $\mathrm{dREN}$ & 59.70 & 22.66 & 9.54 & 6.01 & 1.52 & 0.56 \\
$\mathrm{dEPS}$ & 5.25 & 84.69 & 0.65 & 7.46 & 1.21 & 0.73 \\
$\mathrm{dGDP}$ & 19.22 & 12.63 & 65.14 & 1.68 & 0.58 & 0.75 \\
$\mathrm{dCO}_{2}$ & 33.86 & 13.64 & 9.56 & 35.92 & 3.48 & 3.54 \\
$\mathrm{dOGCN}^{\mathrm{dEDU}}$ & 57.47 & 21.80 & 6.97 & 6.47 & 5.78 & 1.51 \\
\hline
\end{tabular}

Variation in response variable explained by the impulse variables in the columns (10 periods ahead)

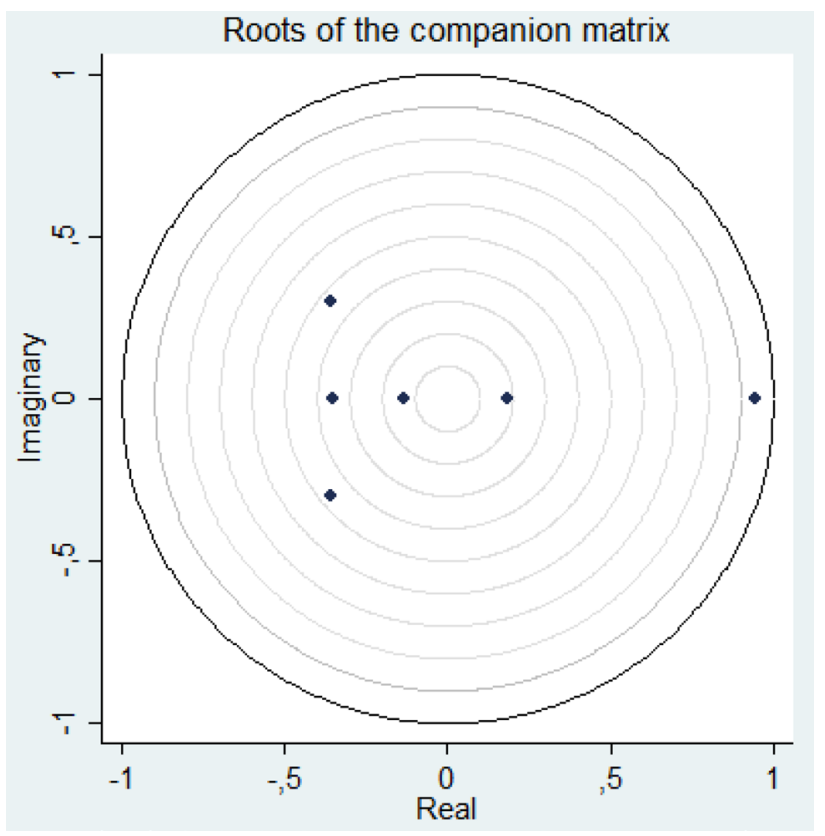

Fig. 3 Roots of the companion matrix — panel A 


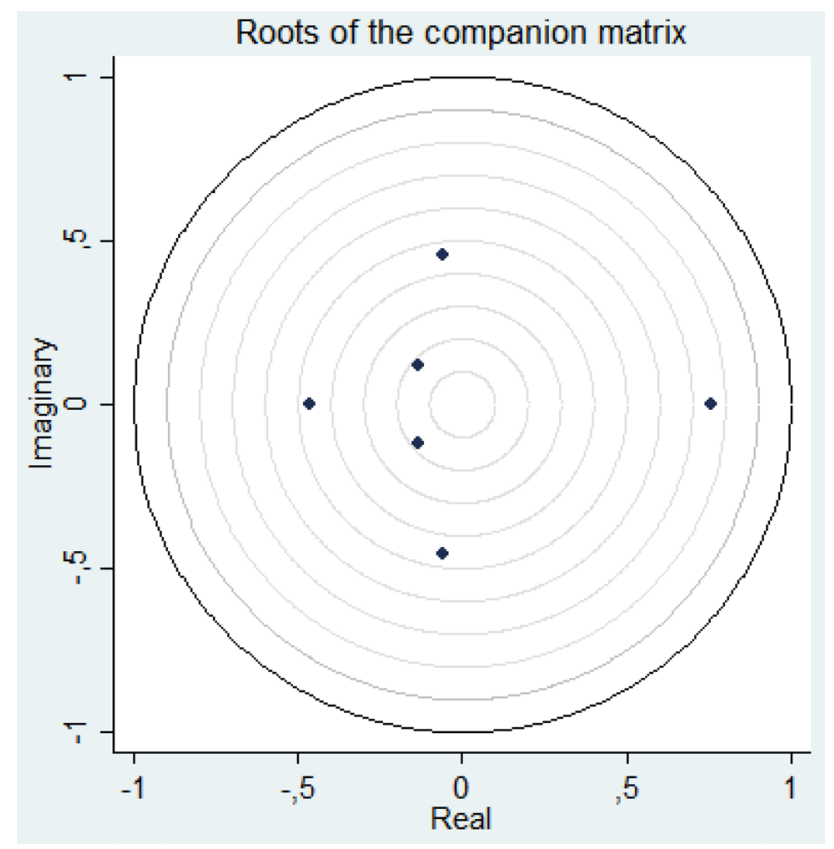

Fig. 4 Roots of the companion matrix — panel B 

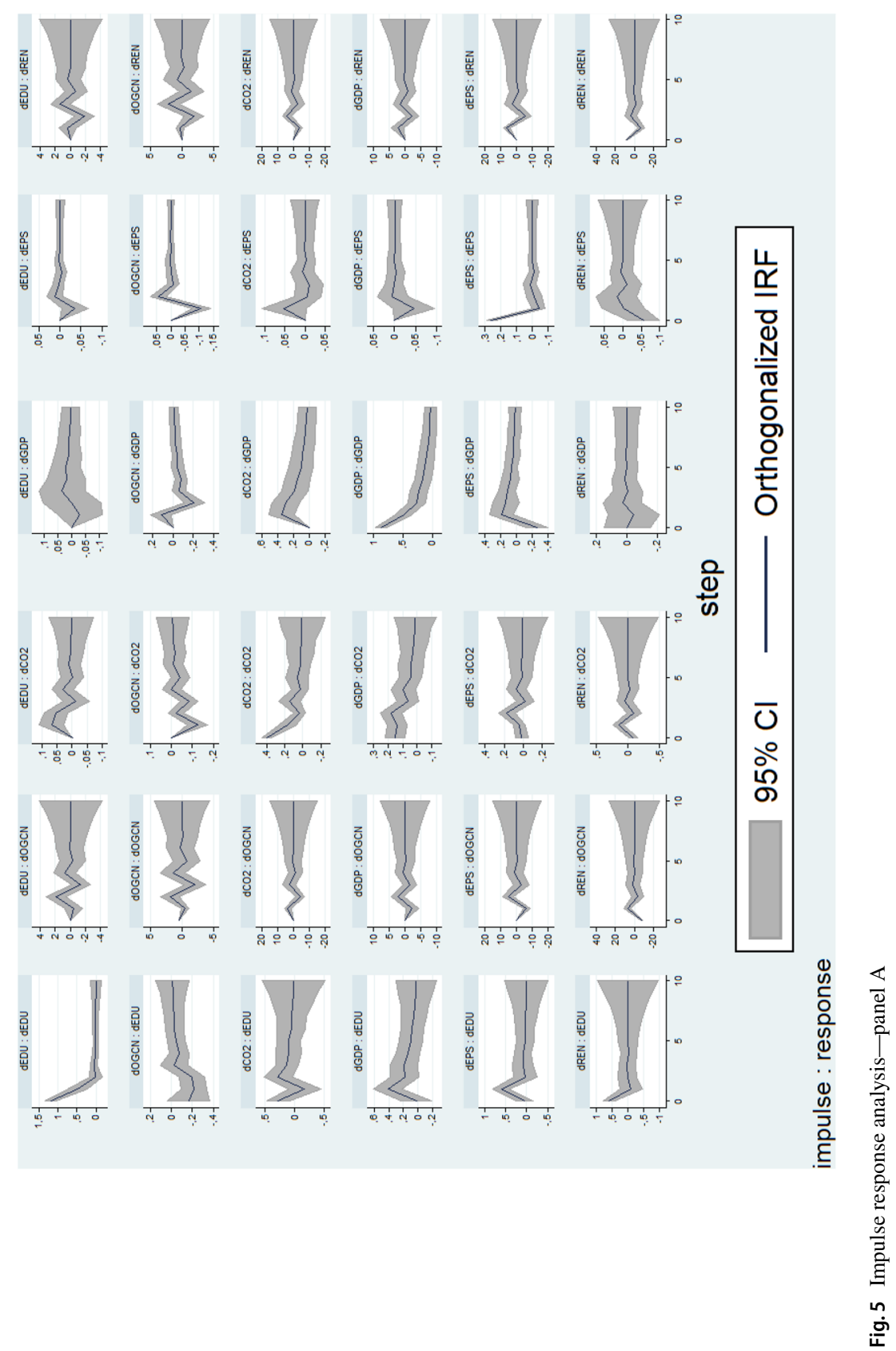

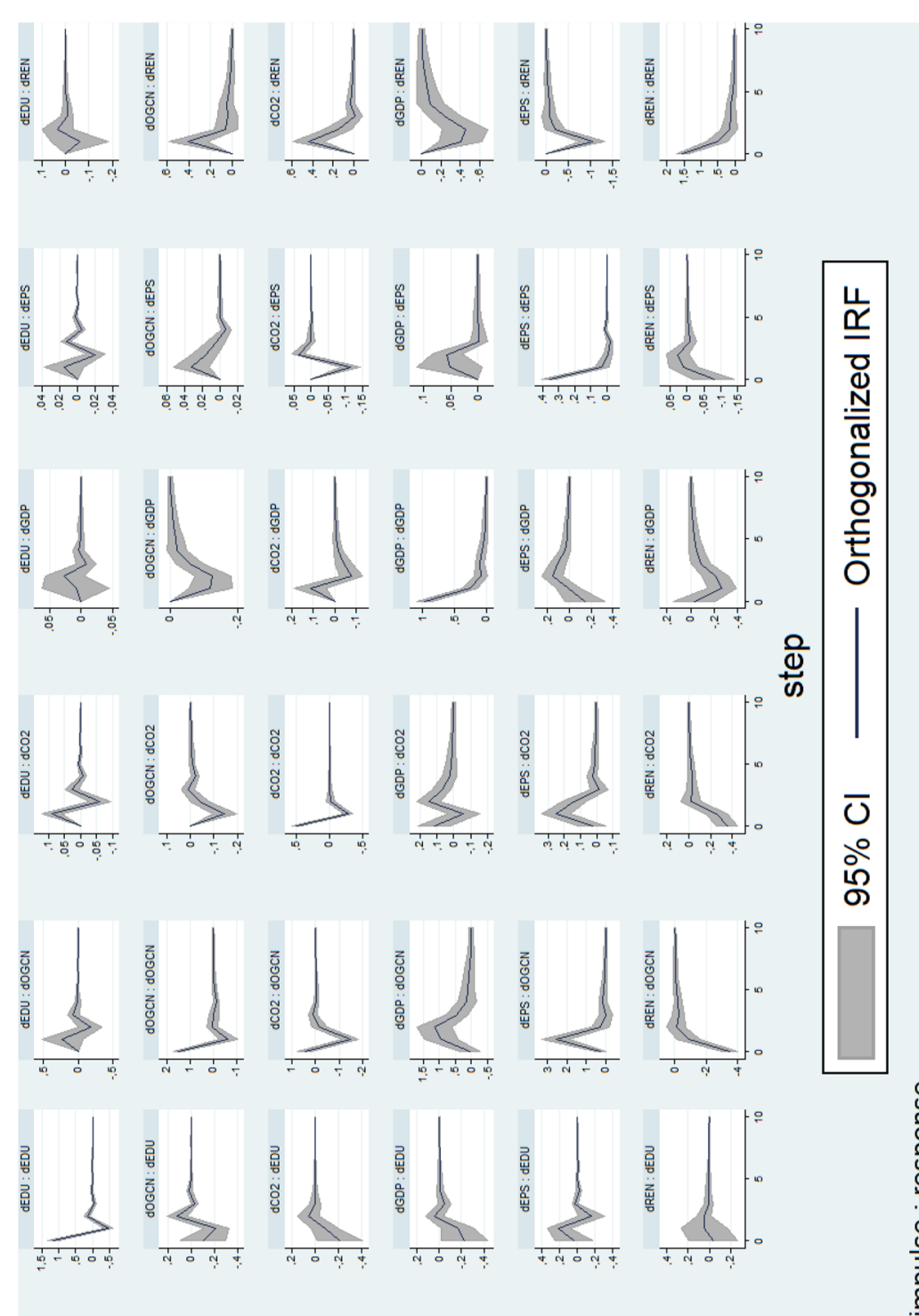

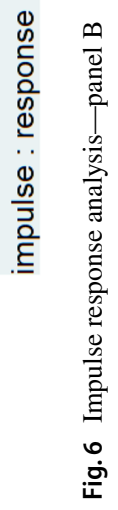


Funding Open access funding provided by D'Annunzio University of Chieti - Pescara within the CRUICARE Agreement.

\section{Declarations}

Conflict of interest On behalf of all the authors, the corresponding author states that there is no conflict of interest.

Open Access This article is licensed under a Creative Commons Attribution 4.0 International License, which permits use, sharing, adaptation, distribution and reproduction in any medium or format, as long as you give appropriate credit to the original author(s) and the source, provide a link to the Creative Commons licence, and indicate if changes were made. The images or other third party material in this article are included in the article's Creative Commons licence, unless indicated otherwise in a credit line to the material. If material is not included in the article's Creative Commons licence and your intended use is not permitted by statutory regulation or exceeds the permitted use, you will need to obtain permission directly from the copyright holder. To view a copy of this licence, visit http://creativecommons.org/licen ses/by/4.0/.

\section{References}

Alper, A., \& Oguz, O. (2016). The role of renewable energy consumption in economic growth: Evidence from asymmetric causality. Renewable and Sustainable Energy Reviews, 60, 953-959. https://doi. org/10.1016/j.rser.2016.01.123

Andrews, D. W. K., \& Lu, B. (2001). Consistent model and moment selection procedures for GMM estimation with application to dynamic panel data models. Journal of Econometrics, 101(1), 123-164.

Andrews-Speed, P. (2016). Applying institutional theory to the low-carbon energy transition. Energy Research and Social Science, 13, 216-225. https://doi.org/10.1016/j.erss.2015.12.011

Arellano, M., \& Bover, O. (1995). Another look at the instrumental variable estimation of error-components models. Journal of Econometrics, 68, 29-51.

Baiocchi, G., Minx, J., \& Hubacek, K. (2010). The impact of social factors and consumer behavior on carbon dioxide emissions in the United Kingdom. Journal of Industrial Ecology, 14, 50-72. https:// doi.org/10.1111/j.1530-9290.2009.00216.x

Baltagi, B. H. (2005). Econometric analysis of panel data (3rd ed.). Wiley.

Bimonte, S. (2002). Information access, income distribution, and the Environmental Kuznets Curve. Ecological Economics, 41, 145-156. https://doi.org/10.1016/S0921-8009(02)00022-8

Bird, L., Bolinger, M., Gagliano, T., Wiser, R., Brown, M., \& Parsons, B. (2005). Policies and market factors driving wind power development in the United States. Energy Policy, 33, 1397-1407. https://doi.org/10.1016/j.enpol.2003.12.018

Blyth, M. (2002). Great transformations: Economic ideas and institutional change in the twentieth century. Cambridge University Press.

Botta, E., \& Koźluk, T. (2014). Measuring Environmental Policy Stringency in OECD Countries. OECD Econ. Dep. Work. Pap. No. 1177 47. https://doi.org/10.1787/5jxrjnc45gvg-en

Bourcet, C. (2020). Empirical determinants of renewable energy deployment: A systematic literature review. Energy Economics, 85, 104563. https://doi.org/10.1016/j.eneco.2019.104563

Büchs, M., \& Schnepf, S. V. (2013). Who emits most? Associations between socio-economic factors and UK households' home energy, transport, indirect and total $\mathrm{CO}_{2}$ emissions. Ecological Economics, 90, 114-123. https://doi.org/10.1016/j.ecolecon.2013.03.007

Can Şener, ŞE., Sharp, J. L., \& Anctil, A. (2018). Factors impacting diverging paths of renewable energy: A review. Renewable and Sustainable Energy Reviews, 81, 2335-2342. https://doi.org/10.1016/j. rser.2017.06.042

Carley, S. (2009). State renewable energy electricity policies: An empirical evaluation of effectiveness. Energy Policy, 37, 3071-3081. https://doi.org/10.1016/j.enpol.2009.03.062 
Chang, T. H., Huang, C. M., \& Lee, M. C. (2009). Threshold effect of the economic growth rate on the renewable energy development from a change in energy price: Evidence from OECD countries. Energy Policy, 37, 5796-5802. https://doi.org/10.1016/j.enpol.2009.08.049

Chien, T., \& Hu, J. L. (2008). Renewable energy: An efficient mechanism to improve GDP. Energy Policy, 36, 3045-3052. https://doi.org/10.1016/j.enpol.2008.04.012

Dasgupta, S., De Cian, E., \& Verdolini, E. (2016). WIDER Working Paper 2016/17. The political economy of energy innovation.

de Serres, A., Murtin, F., \& Nicoletti, G. (2010). A framework for assessing green growth policies. OECD Economics Department Working Papers. https://doi.org/10.1787/5kmf2xvcmkf-en

EC (2019). Communication from the Commission to the European Parliament, the European Council, the Council, the European economic and social committee and the Committee of the regions. https:// eur-lex.europa.eu/legal-content

EC (2021). Renewable energy. https://ec.europa.eu/energy/en/topics/renewable-energy

Gan, J., \& Smith, C. T. (2011). Drivers for renewable energy: A comparison among OECD countries. Biomass and Bioenergy, 35, 4497-4503. https://doi.org/10.1016/j.biombioe.2011.03.022

Gan, L., Eskeland, G. S., \& Kolshus, H. H. (2007). Green electricity market development: Lessons from Europe and the US. Energy Policy, 35, 144-155. https://doi.org/10.1016/j.enpol.2005.10.008

Georgatzi, V. V., Stamboulis, Y., \& Vetsikas, A. (2020). Examining the determinants of $\mathrm{CO}_{2}$ emissions caused by the transport sector: Empirical evidence from 12 European. Economic Analysis and Policy, 65, 11-20. https://doi.org/10.1016/j.eap.2019.11.003

Henriques, I., \& Sadorsky, P. (2008). Oil prices and the stock prices of alternative energy companies. Energy Economics, 30, 998-1010. https://doi.org/10.1016/j.eneco.2007.11.001

Hille, E., \& Möbius, P. (2019). Environmental policy, innovation, and productivity growth: Controlling the effects of regulation and endogeneity. Environmental and Resource Economics, 73, 1315-1355. https://doi.org/10.1007/s10640-018-0300-6

Holtz-Eakin, D., Newey, W., \& Rosen, H. S. (1988). Estimating vector autoregressions with panel data. Econometrica. https://doi.org/10.2307/1913103

Huang, M. Y., Alavalapati, J. R. R., Carter, D. R., \& Langholtz, M. H. (2007). Is the choice of renewable portfolio standards random? Energy Policy, 35, 5571-5575. https://doi.org/10.1016/j.enpol.2007.06. 010

IEA (2019). Market Report Series: Renewables 2019. Analysis and Forecasts to 2024. OECD/IEA.

IEA (2020). Market Report Series: Renewables 2020. Analysis and Forecasts to 2025. OECD/IEA

IRENA (2018). Renewable Energy Prospects for the European Union. Bohn.

Kahia, M., Aïssa, M. S. B., \& Lanouar, C. (2017). Renewable and non-renewable energy use-Economic growth nexus: The case of MENA Net Oil Importing Countries. Renewable and Sustainable Energy Reviews, 71, 127-140. https://doi.org/10.1016/j.rser.2017.01.010

Love, I., \& Zicchino, L. (2006). Financial development and dynamic investment behavior: Evidence from panel VAR. The Quarterly Review of Economics and Finance, 46, 190-210. https://doi.org/10. 1016/j.qref.2005.11.007

Lutkepohl, H. (2005). New introduction to multiple time series analysis. Springer.

Marques, A. C., \& Fuinhas, J. A. (2011). Drivers promoting renewable energy: A dynamic panel approach. Renewable and Sustainable Energy Reviews, 15, 1601-1608. https://doi.org/10.1016/j. rser.2010.11.048

Marques, A. C., \& Fuinhas, J. A. (2012). Is renewable energy effective in promoting growth? Energy Policy, 46, 434-442. https://doi.org/10.1016/j.enpol.2012.04.006

Marques, A. C., Fuinhas, J. A., \& Pires Manso, J. R. (2010). Motivations driving renewable energy in European countries: A panel data approach. Energy Policy, 38, 6877-6885. https://doi.org/10. 1016/j.enpol.2010.07.003

Menegaki, A. N. (2011). Growth and renewable energy in Europe: A random effect model with evidence for neutrality hypothesis. Energy Economics, 33, 257-263. https://doi.org/10.1016/j.eneco.2010.10. 004

Menz, F. C., \& Vachon, S. (2006). The effectiveness of different policy regimes for promoting wind power: Experiences from the states. Energy Policy, 34, 1786-1796. https://doi.org/10.1016/j.enpol. 2004.12.018

Narayan, P. K., \& Smyth, R. (2008). Energy consumption and real GDP in G7 countries: New evidence from panel cointegration with structural breaks. Energy Economics, 30, 2331-2341. https://doi.org/ 10.1016/j.eneco.2007.10.006 
Narbel, P. A. (2013). What is really behind the adoption of new renewable electricity generating technologies? Energy for Sustainable Development, 17(4), 386-390.

Neves, A. S., Cardoso, A., \& Patrício, M. (2020). Determinants of $\mathrm{CO}_{2}$ emissions in European Union countries: Does environmental regulation reduce environmental pollution? Economic Analysis and Policy, 68, 114-125. https://doi.org/10.1016/j.eap.2020.09.005

Nickell, S. (1981). Biases in dynamic models with fixed effects. Econometrica. https://doi.org/10.2307/ 1911408

Nilsson, M., Nilsson, L. J., Hildingsson, R., Stripple, J., \& Eikeland, P. O. (2011). The missing link: Bringing institutions and politics into energy future studies. Futures, 43(10), 1117-1128. https://doi. org/10.1016/j.futures.2011.07.010

North, D. C. (1990). Institutions, institutional change and economic performance. Cambridge University Press.

North, D. C. (2005). Understanding the process of economics change. Princeton University Press.

Ouyang, X., Shao, Q., Zhu, X., He, Q., Xiang, C., \& Wei, G. (2019). Environmental regulation, economic growth and air pollution: Panel threshold analysis for OECD countries. Science of the Total Environment, 657, 234-241. https://doi.org/10.1016/J.SCITOTENV.2018.12.056

Polzin, F., Migendt, M., Täube, F. A., \& von Flotow, P. (2015). Public policy influence on renewable energy investments-A panel data study across OECD countries. Energy Policy, 80, 98-111. https:// doi.org/10.1016/j.enpol.2015.01.026

Sadorsky, P. (2009a). Renewable energy consumption, $\mathrm{CO}_{2}$ emissions and oil prices in the $\mathrm{G} 7$ countries. Energy Econ., 31, 456-462. https://doi.org/10.1016/j.eneco.2008.12.010

Sadorsky, P. (2009b). Renewable energy consumption and income in emerging economies. Energy Policy, 37, 4021-4028. https://doi.org/10.1016/j.enpol.2009.05.003

Salim, R. A., \& Rafiq, S. (2012). Why do some emerging economies proactively accelerate the adoption of renewable energy? Energy Economics, 34, 1051-1057. https://doi.org/10.1016/j.eneco.2011.08. 015

Shrimali, G., \& Kniefel, J. (2011). Are government policies effective in promoting deployment of renewable electricity resources? Energy Policy, 39, 4726-4741. https://doi.org/10.1016/j.enpol.2011.06. 055

Silk, J. I., \& Joutz, F. L. (1997). Short and long-run elasticities in US residential electricity demand: A co-integration approach. Energy Economics, 19, 493-513. https://doi.org/10.1016/S0140-9883(97) 01027-X

Smith, A., Stirling, A., \& Berkhout, F. (2005). The governance of sustainable socio-technical transitions. Research Policy, 34, 1491-1510. https://doi.org/10.1016/j.respol.2005.07.005

Sovacool, B. K. (2009). Rejecting renewables: The socio-technical impediments to renewable electricity in the United States. Energy Policy, 37, 4500-4513. https://doi.org/10.1016/j.enpol.2009.05.073

Vachon, S., \& Menz, F. C. (2006). The role of social, political, and economic interests in promoting state green electricity policies. Environmental Science and Policy, 9, 652-662. https://doi.org/10.1016/j. envsci.2006.07.005

Valdés Lucas, J. N., Escribano Francés, G., \& San Martın González, E. (2016). Energy security and renewable energy deployment in the EU: Liaisons dangereuses or virtuous circle? Renewable and Sustainable Energy Reviews., 62, 1032-1046.

van Ruijven, B., \& van Vuuren, D. P. (2009). Oil and natural gas prices and greenhouse gas emission mitigation. Energy Policy, 37, 4797-4808. https://doi.org/10.1016/j.enpol.2009.06.037

Wang, X., \& Shao, Q. (2019). Non-linear effects of heterogeneous environmental regulations on green growth in G20 countries: Evidence from panel threshold regression. Science of the Total Environment, 660, 1346-1354. https://doi.org/10.1016/J.SCITOTENV.2019.01.094

Westerlund, J. (2007). Testing for error correction in panel data. Oxford Bulletin of Economics and Statistics, 69, 709-748. https://doi.org/10.1111/j.1468-0084.2007.00477.x

Xie, R., Yuan, Y., \& Huang, J. (2017). Different types of environmental regulations and heterogeneous influence on green productivity: Evidence from China. Ecological Economics, 132, 104-112. https://doi.org/10.1016/J.ECOLECON.2016.10.019

Zarnikau, J. (2003). Consumer demand for "green power" and energy efficiency. Energy Policy, 31, 1661-1672. https://doi.org/10.1016/S0301-4215(02)00232-X

Publisher's Note Springer Nature remains neutral with regard to jurisdictional claims in published maps and institutional affiliations. 


\section{Authors and Affiliations}

\section{Alessandro Marra $^{1}$ (1) $\cdot$ Emiliano Colantonio $^{1}$}

$\triangle$ Alessandro Marra

alessandro.marra@unich.it

Emiliano Colantonio

emiliano.colantonio@unich.it

1 University d'Annunzio of Chieti and Pescara, Pescara, Italy 